\title{
Lietuvos Provincijos atkūrimo grupè Afganistane: tinklaveikos fenomenas
}

\begin{abstract}
Straipsnyje analizuojama Lietuvos Provincijos atkūrimo grupès (toliau - PAG) veikla Afganistano Goro provincijoje. Ypatingas demesys skiriamas karių ir civilių bendradarbiavimo dimensijai. Straipsnyje siekiama parodyti, kad karių ir civilių veiklos organizavimas Lietuvos PAG nukrypsta nuo tradiciškai hierarchinès karinių struktūrų organizacinès logikos ir atspindi kitose - ekonominèje, socialinèje, politinèje - gyvenimo srityse ịsitvirtinančius tinklaveikos fenomeno principus. Straipsnio tikslui pasiekti yra pasitelkiama sociologo Manuelio Castellso tinklaveikos visuomenès teorija, kurios idejos yra išplečiamos ị iki šiol šios teorijos rẻmuose neanalizuotą karinę sriț. Tokiu būdu tinklaveikos fenomeno principai yra sugretinami su NATO visaapimančio požiūrio (angl. comprehensive approach) principais, o gautų paralelių patikimumas yra tikrinamas atliekant kokybinę, ekspertiniais interviu pagrịstą, Lietuvos PAG veiklos analizę.
\end{abstract}

\section{Ivadas}

Pokyčiai tarptautinio saugumo aplinkoje neišvengiamai prisideda prie tarptautinių organizacijų - taip pat ir NATO - vykdomų užduočių kaitos. Po Šaltojo karo pabaigos išaugęs nestabilumo lygis paskatino NATO ị savo užduočiu spektrą įtraukti ekspedicines operacijas, kuriomis siekiama prisidèti prie krizinių situacijų sprendimo už euroatlantinès erdvės ribų. Remiantis NATO atstovais, vienas iš svarbiausių tokių operacijų aspektų yra gebẻjimas lanksčiai reaguoti ị situaciją, atsižvelgiant i jos kompleksišką - ekonominius, politinius, socialinius ir karinius aspektus apimančią - sanklodą. Dèl šios priežasties Aljanso strateginiuose dokumentuose yra pabrèžiama visaapimančio požiūrio (angl. comprehensive approach) krizių valdymo srityje igyvendinimo svarba.

Pagrindinè idèja, slypinti už „visaapimančio požiūrio“ termino, gali būti apibūdinta kaip politinių, civilinių ir karinių priemonių sujungimas, siekiant bendro tikslo krizių valdymo ir pokonfliktinio atstatymo operacijose. Tam bū-

\footnotetext{
"Justina Budginaite - Hamburgo universiteto Taikos studijų ir saugumo politikos instituto magistrantè. Adresas korespondencijai: Beim Schlump 83, 20144 Hamburgas, Vokietija, tel. 865345 620,

el. p. juste.budginaite@gmail.com
} 
tina bendra skirtingų profilių veikèjų - karių, politinių ir nevyriausybinių organizacijų (toliau - NVO) atstovų - atsakomybè už operacijos igyvendinimą, visapusis atvirumas sujungiant stipriąsias kiekvieno veikejjo savybes, mandatus ir šių veikejjų sprendimų prièmimo autonomijos išlaikymas. ${ }^{1}$ NATO įsitraukimas ị tarptautinès bendruomenès veiklą Afganistane, kur Aljansas vadovauja Tarptautinių saugumo paramos pajėgų (angl. International Security Assistance Forces, ISAF) misijai, lèmè tai, kad visaapimantis požiūris neliko vien teorinè sąvoka, įtvirtinta strateginiuose dokumentuose, bet buvo nedelsiant pradètas praktiškai igyvendinti Aljanso šalių narių ir partnerių vadovaujamose Provincijų atkūrimo grupèse (toliau - PAG). ${ }^{2}$

Nors NATO atstovai nuolat pabrèžia visaapimančio požiūrio igyvendinimo prasmę ir svarbą, šios koncepcijos praktinis pritaikymas kelia nemažai iššukių. Viena pagrindinių sisteminių problemų, trukdančių sklandžiam karinių pajegų ir civilinių organizacijų bendradarbiavimui krizių paliestose teritorijose, kyla dèl reikšmingų karių ir civilių darbo kultūrų skirtumų. Kadangi karinių struktūrų paskirtis - valstybès saugumo ir gynybos politikos igyvendinimas - lemia aukšto atsakomybès ir atskaitomybès lygio poreikị, tradiciškai kariuomenè yra suvokiama kaip griežtai reglamentuota struktūra, paremta hierarchiniais subordinacijos ryšiais, savo veiklą organizuojanti pagal vertikalią top-down vadovavimo ir kontrolès sistemą ir pasižyminti aukštu izoliacijos nuo plačiosios visuomenès lygiu. PAG veikla, priešingai, yra pagrịsta lanksčiu, nerutinizuotu ir horizontaliu lygmeniu plètojamu karių ir civilių bendradarbiavimu. Dèl šios priežasties, siekis PAG užduotis ịgyvendinti remiantis visaapimančio požiūrio principais yra nemenkas iššǔkis tiek prie griežtai reglamentuotos veiklos vykdymo ịpratusiems karinių struktūrų atstovams, tiek kur kas lanksčiau veikiantiems civiliams.

Atsižvelgiant $\mathfrak{i}$ tai, kad bendradarbiavimas PAG formate yra nauja patirtis tiek kariams, tiek civiliams, šiame straipsnyje yra siekiama ịvertinti visaapimančio požiūrio igyvendinimu pagrįstos karių ir civilių sąveikos PAG galimybes ir ribas. Straipsnio tikslui pasiekti yra pasitelkiama sociologo Manuelio Castellso tinklaveikos visuomenès (angl. network society) teorija ${ }^{3}$, kurios pagrindine teze teigiama, jog pastaruoju metu ekonomineje, politinejje, socialineje sferose yra pastebimi didelio masto organizaciniai pokyčiai: anks-

\footnotetext{
${ }^{1} \mathrm{NATO}$, ,A ‘Comprehensive Approach’ to crisis management“, www.nato.int/cps/en/natolive/topics_51633.htm [žiūrèta 201208 29].

${ }^{2}$ PAG kaip karinių ir civilinių pajègumų sujungimo instrumentas buvo įgyvendinamas ir Irake, tačiau šiame straipsnyje apsiribojama PAG, veikiančių Afganistane, analize.

3 Manuel Castells, Informacijos amžius: ekonomika, visuomene ir kultūra. Tinklaveikos visuomenès raida (I tomas), Poligrafija ir informatika, 2005.
} 
čiau vyravusios hierarchinės veiklos organizavimo ir koordinavimo struktūros yra pakeičiamos horizontaliąja veiklos logika pagrịstomis tinklo struktūromis. Pagrindine vykstančios reorganizacijos priežastimi laikoma nepaslanki procedūrinè hierarchinių struktūrų prigimtis, neatitinkanti pakitusių viešojo gyvenimo principų, kurių esmè yra mobilumas, lankstumas, gebejimas greitai prisitaikyti prie kintančių veiklos sąlygų.

Kadangi krizių valdymo ir pokonfliktinio atstatymo operacijose kariai ir civiliai taip pat susiduria su minètais mobilumo, lankstumo, greito reagavimo reikalavimais, straipsnyje daroma prielaida, kad PAG, greta ekonominių, socialinių, politinių organizacijų, yra karinès prigimties pavyzdys, iliustruojantis, kad ir tradiciškai hierarchiškos karinès struktūros bent iš dalies yra reorganizuojamos ị lanksčiau veikiančias tinklo struktūras. Siekiant patikrinti minètą prielaidą, straipsnyje pristatoma atvejo studija, kurioje, remiantis ekspertiniais interviu su LR karinès misijos ir LR specialiosios misijos Afganistane vadovais, misijoje dalyvavusiais karininkais, civiliais ir NVO atstovu, analizuojama, kaip sèkmingai tinklaveikos fenomeno apraiška karinèje srityje - NATO visaapimančio požiūrio koncepcija - yra igyvendinama Lietuvos vadovaujamoje PAG Afganistano Goro provincijoje.

\section{Teorinès tinklaveikos fenomeno pasekmès karinei sferai}

Tinklaveikos visuomenés teorija yra pagrịsta dviejų organizacinių formų hierarchijų ir tinklų - savybių palyginimu ir jų adekvatumo informacionalizmo eroje $^{4}$ vykdomoms veikloms analize. Teorijoje teigiama, kad hierarchinès struktūros, kurių pavyzdžiais laikomos didžiosios korporacijos, formaliosios biurokratinės organizacijos (tarp jų ir kariuomenè) pasižymi aiškiomis veiklos ribomis ir pavaldumo ryšiais, struktūruotu informacijos perdavimo mechanizmu ir formaliomis sprendimų prièmimo procedūromis, todèl yra pritaikytos standartizuotai veiklai vykdyti. ${ }^{5}$ Tokių struktūrų privalumas yra jų patikimumas bei atskaitomybè - gebejjimas koordinuoti vykdomus procesus nuo pradžios iki

\footnotetext{
${ }^{4}$ Tinklaveikos teorijoje išlaikoma analitinè skirtis tarp gamybos būdų (kapitalizmas, etatizmas) ir visuomenès raidos modelių (industrializmas, informacionalizmas). Teorijoje teigiama, kad dabartiniame laikotarpyje vyraujantis gamybos būdas išlieka kapitalizmas, tačiau kapitalistinių santykių raidos modelis yra pakitęs iš industrializmo, kuriame pagrindinis produktyvumo šaltinis buvo energijos šaltiniai, ị informacionalizmą, kuriame svarbiausias vaidmuo priklauso žinių skleidimui, informacijos apdorojimui ir komunikacijos technologijoms. Castells, 28-29.

${ }^{5}$ Walter W. Powell, „Neither Market Nor Hierarchy: Network Forms of Organization“, Research in Organizational Behavior, Vol. 12, 1990, 303.
} 
galo. Dèl šių specifinių bruožų efektyviam hierarchinių struktūrų funkcionavimui yra būtinas situacijos pastovumas - susidūrus su staigiais, nenumatytais pokyčiais išryškẻja hierarchijų nepaslankumas, procedūrinė vykdomos veiklos specifika, negebejimas taikytis prie permainų.

Tinklai, priešingai nei hierarchijos, gali sèkmingai prisitaikyti prie greitai kintančios aplinkos ir specifinių konkrečioje situacijoje vykdomai veiklai kylančių reikalavimų. Pagrindinè to priežastis yra tarpusavio priklausomybe pagrịsti tinklo narių ryšiai - jie dalijasi atsakomybe už vykdomą veiklą ne pagal hierarchinès subordinacijos principą, bet remdamiesi tokiu vaidmenų pasidalijimu, kai vieni tinklo nariai yra priklausomi nuo kitų narių kontroliuojamų resursų. ${ }^{6}$ Tai reiškia, kad tinklui priklausantys dalyviai nèra ịtraukiami i bendrą vadovavimo ir kontrolès sistemą, veikia decentralizuotai, tačiau yra susaistyti bendro veiklos tikslo. ${ }^{7}$

Efektyvus išsamios informacijos generavimas yra pagrindinis tinklo organizacinès formos privalumas. Kadangi tinklo dalyviai nepriklauso bendrai formaliai struktūrai, kiekvienas iš jų per savo autonomišką veiklą yra pajẻgus igyti daugiau ir įvairesnio pobūdžio informacijos, kurią vèliau gali pritaikyti tinklo veikloje. ${ }^{8}$ Nepaisant šių privalumų, tinklo organizaciné forma tik palyginti neseniai èmè įsigalèti hierarchinių struktūrų atžvilgiu: tinklų pagrindinè problema visada buvo koordinacijos trūkumas, lėmęs jų nepatikimumą. ${ }^{9} \mathrm{Si}$ tuacija pasikeite, išplitus pažangioms komunikacijų ir informacinèms technologijoms, sudarančioms sąlygas pasireikšti tinklo - ne kaip pastovios formalizuotos struktūros, bet kaip nenutrūkstamo proceso - privalumams.

1-oje lenteleje pateikiami susisteminti industrializmo ir informacionalizmo visuomenès raidos modelių bruožai. Ypatingas dèmesys skiriamas „konfliktuojančių“ veiklos organizavimo formų - hierarchijų ir tinklu - savybių palyginimui, remiantis pavaldumo ryšių, informacijos perdavimo, privalumų ir trūkumų kriterijais.

\footnotetext{
${ }^{6}$ Ten pat, 303.

${ }^{7}$ Henry Mintzberg, Structure in Fives: Designing Effective Organizations, New Jersey: Prentice-Hall, Inc., 1983, 95.

${ }^{8}$ Ten pat, 304.

${ }^{9}$ Castells, 181.
} 
1 lentelè. Veiklos organizavimo ypatybès:

industrializmas vs. informacionalizmas

\begin{tabular}{|c|c|c|c|}
\hline & & \multicolumn{2}{|c|}{ Visuomenès raidos modelis } \\
\hline & & Industrializmas & Informacionalizmas \\
\hline \multicolumn{2}{|c|}{ Produktyvumo šaltinis } & energija & žinios \\
\hline \multicolumn{2}{|c|}{ Efektyvios veiklos principai } & $\begin{array}{c}\text { pastovumas, nuspéjamumas, } \\
\text { kontrolè }\end{array}$ & $\begin{array}{c}\text { lankstumas, mobilumas, reagavimo } \\
\text { greitis }\end{array}$ \\
\hline \multicolumn{2}{|c|}{$\begin{array}{l}\text { Laukiamas veiklos } \\
\text { rezultatas }\end{array}$} & $\begin{array}{l}\text { masinis, standartizuotas } \\
\text { produktas }\end{array}$ & inovatyvus, tarpdisciplininis produktas \\
\hline \multicolumn{2}{|c|}{ Veiklos organizavimo forma } & hierarchija & tinklas \\
\hline \multirow{2}{*}{$\begin{array}{l}\mathrm{S} \\
\mathrm{A} \\
\mathrm{V}\end{array}$} & Pavaldumo ryšiai & $\begin{array}{l}\text { vertikali subordinacija, bendra } \\
\text { struktūra }\end{array}$ & $\begin{array}{l}\text { horizontalioji tarpusavio priklausomybè, } \\
\text { autonomija }\end{array}$ \\
\hline & $\begin{array}{l}\text { Informacijos } \\
\text { perdavimas }\end{array}$ & centralizuotas & decentralizuotas \\
\hline $\begin{array}{l}\mathrm{Y} \\
\mathrm{B}\end{array}$ & Privalumai & $\begin{array}{l}\text { patikimumas, atskaitomybè, } \\
\text { gebejjimas koordinuoti veiklą nuo } \\
\text { pradžios iki galo }\end{array}$ & $\begin{array}{l}\text { informacijos sklaida, gebėjimas spręsti } \\
\text { kompleksiškas problemas }\end{array}$ \\
\hline $\begin{array}{l}\dot{E} \\
S\end{array}$ & Trūkumai & $\begin{array}{c}\text { nepaslankumas, } \\
\text { procedūriškumas, formalumas }\end{array}$ & koordinacijos, atskaitomybès stoka \\
\hline
\end{tabular}

Kalbant apie karines organizacijas, galima pastebèti, kad kontekstas, kuriame jos yra priverstos veikti, taip pat tampa vis kompleksiškesnis: stabilumo užtikrinimas, atkūrimas po konfliktų, pagalba civilinėms administracijoms yra naujos užduotys, papildžiusios tradicinę karinių pajègų funkciją - valstybės gynybą. ${ }^{10}$ Atsižvelgiant $\mathfrak{i}$ šiuos funkcijų pokyčius, galima manyti, kad siekiant efektyviai vykdyti naujas kompleksiškas užduotis, hierarchinè kariuomenès organizacinè specifika turi būti bent minimaliai decentralizuojama pagal tinklaveikos logiką. Tai reiškia, kad, pirma, saugumo problemoms spręsti turi būti panaudota jau ne elementari karinè jèga, tačiau privalo būti rastas tarpdisciplininis sprendimas - karinè jèga turi būti derinama su civilinèmis priemonėmis. Antra, kadangi kompleksiškos saugumo problemos yra greitai evoliucionuojančios, plintančios ị ịvairias žmonių gyvenimo sritis, neįmanoma jų spręsti pagal vieną nustatytą šabloną - karinius ir civilinius pajègumus būtina organizuoti taip, kad jie galètų lanksčiai ir mobiliai reaguoti į nuolat kintančią situaciją. NATO visaapimančio požiūrio igyvendinimas ISAF misijoje Afganistane yra vienas iš aktualiausių bandymų formuoti tarpdisciplinines karių ir civilių bendradarbiavimu pagrịstas krizių valdymo komandas.

\footnotetext{
${ }^{10}$ Christopher Dandecker, „Building Flexible Forces for the 21st Century“, žr: Giuseppe Caforio, sudar., Handbook of the Sociology of the Military, New York: Springer, 2006, 412.
} 


\section{Visaapimantis požiūris - tinklaveikos fenomeno apraiška karinėje sferoje}

NATO visaapimančio požiūrio koncepcija aiškiai atspindi išplèstą - ekonominius, politinius, socialinius, karinius aspektus apimantị - požiūrị i saugumą. Nors siekis spręsti tokias kompleksiškas saugumo problemas, pasitelkiant koordinuotas karių ir civilių komandas, pats savaime nèra naujas reiškinys, unikalu yra tai, kad visaapimančiu požiūriu iš šios partnerystès yra siekiama panaikinti vieno elemento dominavimo kito atžvilgiu galimybę, t. y. pereiti nuo vertikalaus prie horizontaliojo operacijų organizavimo ir koordinavimo būdo. Minètasis tikslas yra ịtvirtinamas, nurodant, kad ị krizių valdymo misijas ịtraukiami politinis, karinis, civilinis elementai turi bendradarbiauti dèl bendro tikslo, tuo pačiu metu gerbdami vieni kitų veiklos specifiką, mandatus, vaidmenis ir sprendimų priemimo autonomiją. ${ }^{11}$ Šiuo aspektu siekiama išlaikyti visų misijoje dalyvaujančių veikejjų specifinius veiklos pobūdžio ir jos organizavimo bruožus, kadangi sèkmingai veiklai kompleksiškoje aplinkoje reikalinga ne suniveliuota ir šabloniška krizių valdymo komanda, o lanksti, prie konkrečioje situacijoje kylančių reikalavimų prisiderinti gebanti horizontalioji struktūra. Tokios veiklos specifikos ịtvirtinimas kuria aiškias paraleles su ịsivyraujančiu tinklaveikos fenomenu - poreikis sujungti skirtingų veikejjų ekspertines žinias ir išeiti už riboto biurokratinio mąstymo ribų ${ }^{12}$ reikalauja garantuoti jiems tam tikrą autonomijos lygì, nes tik nerutinizuotos struktūros gali pasiūlyti kompleksiškos prigimties problemų sprendimus.

Atitinkamai PAG instrumentas yra išskirtinis bandymas formuoti bendrą karių ir civilių komandą, kuri pajegtų veikti trimis dimensijomis - saugumo, administravimo ir ekonominio vystymosi. ${ }^{13}$ Siekiama, kad tokioje komandoje vyrautų konsensusu paremtas sprendimo prièmimo būdas, kuris suderintų komandos diplomatinę, ekonominę ir karinę linijas ir nukreiptų jas bendro tikslo link. ${ }^{14}$ Konsensusui atsirasti yra būtinas bendras skirtingų PAG elementų suvokimas apie aplinką, kurioje yra veikiama, todèl multidisciplininèje, išsamų situacijos vertinimą pateikti gebančioje komandoje turi būti išlaikomas balansas tarp sutarimo dèl bendrų tikslų ir pakankamo skirtingų veikejų naudojamų darbo metodų autonomijos lygio. Taigi karinis ir civilinis elementai turi būti lygiaver-

\footnotetext{
${ }^{11}$ NATO, Comprehensive Approach Action Plan Update, (PASP(2011)0174), NATO International Staff, Political Affairs \& Security Policy, 2011, 4.

${ }^{12}$ NATO, NATO Comprehensive Approach Roundtable, Final Proceedings Report, Washington, D.C., $2009,3$.

${ }^{13}$ NATO, ISAF Provincial Reconstruction Team (PRT) Handbook, Edition 4, 2009, 8.

${ }^{14}$ Ten pat, 36-37.
} 
čiai partneriai - PAG neturi tapti išskirtinai kariniais mechanizmais, savo sudètyje turinčiais ir tam tikrą civilių skaičių. ${ }^{15}$

Esminis veiksnys, turintis užtikrinti vienodą PAG atstovų situacijos suvokimą, yra horizontaliosios informacijos infrastruktūros sukūrimas. Tai ypač aktualu tuose PAG, kuriuose kartu veikia keletas valstybių, kadangi juose būtina ne tik minimizuoti veiklos koordinavimo trukdžius, kylančius dèl skirtingų karių ir civilių veiklos kodų, bet ir spręsti tarpkultūrinio bendravimo problemas. ${ }^{16}$ Šis PAG organizacinès kultūros aspektas iliustruoja bendrą ìvairiose sferose veikiančių organizacijų komunikavimo principų kaitą iš anksčiau vyravusio „poreikio žinoti“ it îsigalinčią „būtinybę dalintis“.

Atsižvelgiant ì minètus aspektus, 2-oje lentelèje pateikiamos paralelès tarp tinklaveikos ir NATO visaapimančio požiūrio koncepcijos principų.

\section{2 lentelè. Visaapimančio požiūrio ịgyvendinimas - tinklaveikos fenomeno apraiška karinèje sferoje}

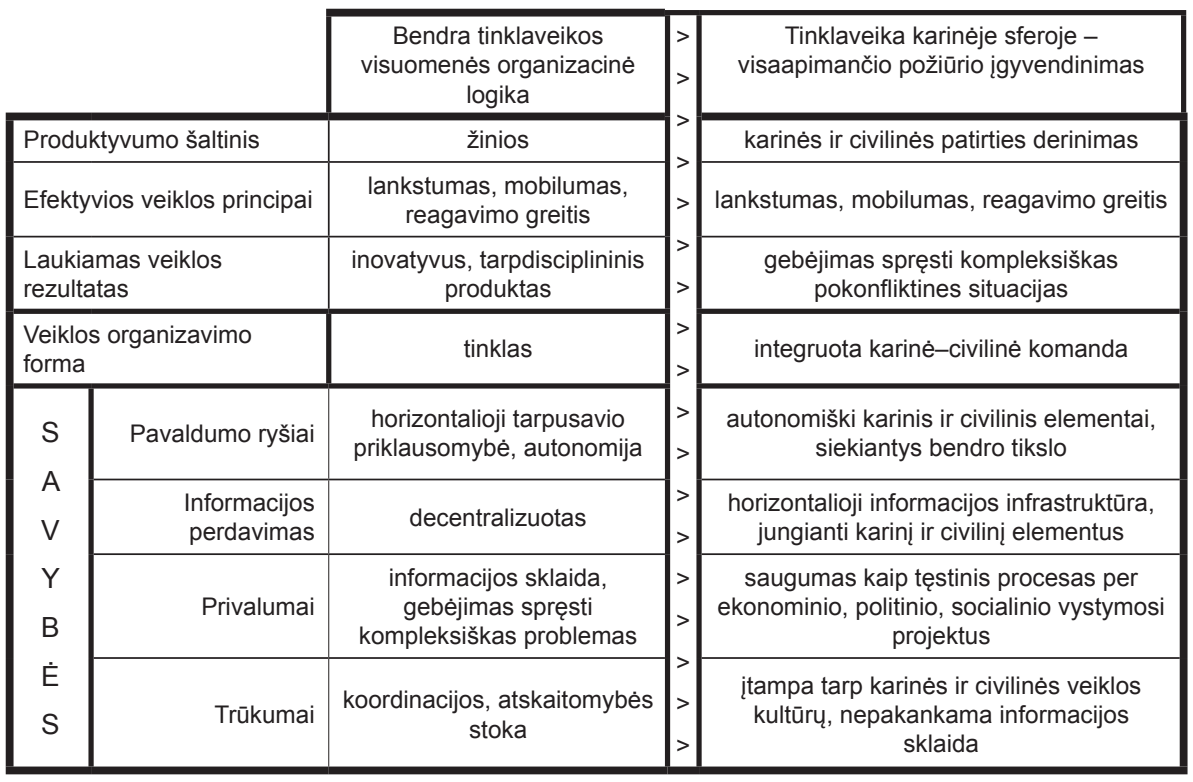

Tiek informacijos infrastruktūros kūrimo, tiek kitų PAG veiklos koordinavimo klausimų sprendimas dideliu mastu priklauso nuo PAG kontroliuojančios šalies nacionalinių biurokratinių tradicijų ir nusistovejusių karių ir civilių ryšių palaikymo būdų ${ }^{17}$. Taip yra dèl to, kad nors PAG yra kontroliuo-

\footnotetext{
${ }^{15}$ Oskari Eronen, „PRT Models in Afghanistan Approaches to Civil-Military Integration“, CMC Finland Civilian Crisis Management Studies, Volume 1(5), 2008, 34-35.

${ }^{16}$ NATO, ISAF Provincial Reconstruction Team (PRT) Handbook, 46.

${ }^{17}$ Eronen, $10-11$.
} 
jami ISAF kariniais operaciniais klausimais, jie tuo pačiu metu yra ir NATO šalių atkūrimo, vystymo ir kitiems civiliniams tikslams sukomplektuoti nacionaliniai vienetai, kurių sprendimo prièmimo procesui ISAF turi minimalią itaką ${ }^{18}$. Nacionalinès PAG komandos yra siunčiamos į Afganistaną su skirtingais mandatais ir, apskritai, suvokimu, kas yra visaapimantis požiūris ir kaip jis turètų būti igyvendintas karinëje-civilinejje komandoje ${ }^{19}$. Remiantis šiuo aspektu, klaidinga manyti, kad visi Afganistane veikiantys PAG yra sukomplektuoti pagal bendrą modeli. Atsižvelgiant $\mathfrak{i}$ tai, kad kiekvienas PAG yra unikalus karinių ir civilinių pajègumų sujungimo atvejis, kitame skyriuje analizuojama Goro provincijoje veikiančios Lietuvos PAG organizavimo ir veiklos specifika.

\section{Karių ir civilių bendradarbiavimo tinklas Lietuvos PAG Goro provincijoje}

Visi PAG, veikiantys Afganistane, yra hierarchiškai organizuotos NATO ISAF struktūros dalis. Nepaisant to, kiekviena iš PAG vadovaujančiu šalių veikia remiantis tokiu PAG modeliu, kuris geriausiai atitinka vietines saugumo, ekonominio išsivystymo bei socialines sąlygas ${ }^{20}$. Šie aspektai lemia PAG - autonomiškų, decentralizuotai veikiančiu ir tarpusavyje nestandartizuotų operacinių padalinių - horizontaliojo tinklo po hierarchiška NATO ISAF struktūra susiformavimą (žr. 1 pav.).

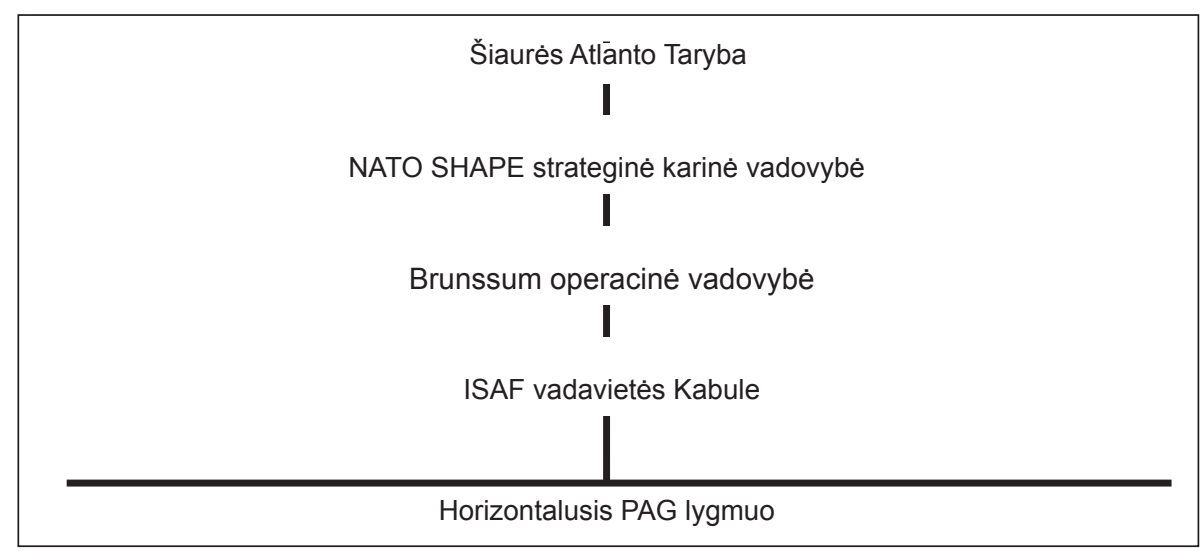

1 pav. Horizontalusis PAG tinklas hierarchinèje NATO ISAF struktūroje

\footnotetext{
${ }^{18}$ NATO, ISAF Provincial Reconstruction Team (PRT) Handbook, 22.

${ }^{19}$ NATO, NATO Comprehensive Approach Roundtable, 5.

${ }^{20}$ Robert M. Perito, „The U.S. Experience with Provincial Reconstruction Teams in Afghanistan. Lessons Identified“, United States Institute of Peace, 2005, 2.
} 
Atliekant ekspertinius interviu su Lietuvos karinëje ir specialioje misijoje Afganistane dirbusiais asmenimis buvo siekta išsiaiškinti, kokia organizacinè logika vyrauja Lietuvos vadovaujamoje PAG Goro provincijoje. Šiam tikslui pasiekti PAG karių ir civilių bendradarbiavimo tinklas analizuotas dviem pagrindiniais aspektais: organizaciniu - aiškintasi, kokia yra PAG formatu itvirtinta karių ir civilių veiklos reglamentavimo ir koordinavimo specifika, ir kultūriniu - tirta, kokią įtaką bendradarbiavimui daro skirtingi karių ir civilių veiklos kodai. Analizè, pagrịtsta šiais dviem aspektais, leidžia išsiaiškinti ne tik tai, kokios yra sudaromos formalios sąlygos kariams ir civiliams veikti kartu toje pačioje operacinëje erdvèje, bet ir tai, kiek šiomis sąlygomis yra įmanoma sèkmingai pasinaudoti dèl nusistovejusių skirtingų karių ir civilių darbo kultūrų.

\subsection{PAG veiklos reglamentavimas}

ISAF misijos rèmuose vykdomos Lietuvos PAG veiklos reglamentavimo lygis yra pakankamai ribotas. Greta LR dalyvavimo tarptautinès bendruomenès veikloje Afganistano Islamo Respublikoje strategijos ${ }^{21}$, pagrindinis dokumentas, reglamentuojantis karių ir civilių veiklą ir tarpusavio sąveiką PAG, yra karinio vieneto ir civilinio elemento sąveikos tvarkos aprašas ${ }^{22}$ . Šis aprašas, kaip minejjo kalbinti ekspertai, yra teisiniai rèmai, tam tikros gairès, nustatančios, kokiose srityse karinis vienetas ir civilinis elementas turi veikti, o ne kaip jie turi vykdyti savo veiklą ir bendradarbiauti tarpusavyje. Toks lankstus veiklos „iforminimo“ būdas leidžia išvengti papildomų procedūrinių trukdžių, kurie iškiltų, jeigu kompleksiškoje ir nepastovioje Afganistano aplinkoje veiktų struktūruotos biurokratinès organizacijos. Kaip pastebejjo buvęs LR specialiosios misijos Afganistane vadovas: „[b]endradarbiavimas per patirtị yra labai išsigryninęs, nusišlifavę kampai. Veikimo sèkmẻ dabar yra nulemta ne kokių nors dokumentų buvimo ar trūkumo, o žmonių: kiek jie yra pajègūs, kiek jie yra tarpusavyje komunikuojantys ir t. t. ${ }^{\text {“23 }}$

Kadangi karinès ir civilinès veiklos sujungimas sudaro PAG kaip instrumento esmę, minimalus šių veiklų procedūrinis reglamentavimas lei-

\footnotetext{
${ }^{21}$ LR Seimas, LR Vyriausybès nutarimas dèl Lietuvos Respublikos dalyvavimo tarptautinès bendruomenès veikloje Afganistano Islamo Respublikoje 2009-2013 metais strategijos patvirtinimo, 2009 m. rugpjūčio 19 d., Nr. 989. http://www3.lrs.1t/pls/inter3/dokpaieska.showdoc_1?p_id=351998\&p_query=\&p_tr2=2 [žiūrèta 201104 10].

${ }^{22}$ LR Krašto apsaugos ministro ir LR Užsienio reikalų ministro įsakymas dẻl Lietuvos Respublikos vadovaujamos Afganistano Islamo Respublikos Goro provincijos atkūrimo grupès veikloje dalyvaujančių karinio vieneto ir civilinio elemento sąveikos tvarkos aprašo, $2009 \mathrm{~m}$. rugsėjo 3 d., Nr. V-846/V-155.

${ }^{23}$ Buvęs LR specialiosios misijos Afganistane vadovas (1), ekspertinis interviu, Vilnius, 20110412.
} 
džia PAG apibūdinti kaip tinklaveikos fenomeno principams pavaldžią, inovatyvią organizaciją. Ji akivaizdžiai išeina už tradiciškai karinèms organizacijoms būdingų procedūriškumo ribų ir turi visas galimybes lanksčiai reaguoti $\mathfrak{i}$ situacijos operacinëje erdvejje pokyčius. Tai patvirtino interviu metu kalbinti karininkai ir civiliai, dalyvavę skirtingose PAG rotacijose ir skirtingose LR specialiosios misijos pamainose, pabrèždami, kad iš jų pateiktos informacijos plačių apibendrinimų apie PAG kaip instrumento specifiką daryti negalima: „, [i]r atskirų valstybiu PAG užduotys skiriasi, ir nacionalinio PAG rotacijų užduotys skiriasi. Aišku, tai labai priklauso nuo vadų, nuo pačios saugumo situacijos, ar daugiau įtampos, ar mažiau. “24 Tokie ekspertų pastebejjimai apie PAG kintamumą, priklausomai nuo esamų aplinkybių, patvirtina PAG kaip karių ir civilių bendradarbiavimo lygmenyje ad hoc veiklos principais pasižyminčios struktūros įtvirtinimą - kiekvienos PAG rotacijos metu tiek dèl išorinių operacinès aplinkos sąlygų, tiek dèl vyraujančios vidinės bendradarbiavimo atmosferos, karių ir civilių veiklos derinimo pobūdis gali stipriai varijuoti.

DèlšiospriežastiesPAGgalibūtiapibūdintaskaipnestandartinis,nedoktrininis darinys: „PAGkaipkarinėorganizacijaištikrųjųneegzistuoja-jinèraneihierarchine, nei kažkokia kitokia prasme egzistuojanti. PAG' as neegzistuoja iš viso kaip toks. ${ }^{\text {“25 }}$ Anot kalbinto eksperto, kai kalbama apie skyrius, batalionus, kuopas, visada yra aišku, kas turima omenyje, o PAG organizacinè logika verčia susimąstyti - yra daug veiksnių, kurie nulemia kaskart skirtingą šio darinio konfigūraciją. Lygindamas PAG su ịprastomis karinemis organizacijomis ekspertas teigè, kad PAG sudarantys karinis vienetas ir civilinis elementas, priklausomai nuo aplinkybių ir užsibrěžtų tikslų, kiekvieną kartą gali būti ir yra skirtingi: „[t]ai priklauso nuo aplinkybių, nuo ìsivaizdavimo, kur turi būti nukreiptas dèmesys. Tai, iš esmès, ir lemia nestandartinio darinio atsiradimą, lemia šiokị tokị nukrypimą nuo ịprastinès hierarchinès karinès organizacijos. ${ }^{\text {“26 }}$

Tai, kad karių ir civilių bendradarbiavimo pobūdis priklauso nuo konkrečioje situacijoje esančių skirtingo veiklos koordinavimo poreikio ir masto, patvirtina ir išsakyta mintis, kad Afganistane veikia ne susitarimai, dokumentai ar reglamentai, o asmeniniai santykiai: „[v]iskas paremta asmeniniais santykiais tiek Afganistano gentinè struktūra, tiek užsienio pajègų, civilių ir karių. Aišku, atskirai karinis vienetas yra kas kita - ten viskas labai griežtai reglamentuota. $\mathrm{O}$ civiliaiirkariai,kitųšaliųatstovaiveikląkoordinuojaperasmeniniussantykius. ${ }^{\text {“27 }}$

\footnotetext{
${ }^{24}$ Karinėje misijoje dalyvavęs karininkas (1), ekspertinis interviu, Vilnius, 20110504.

${ }^{25}$ Buvęs PAG vadas (1), ekspertinis interviu, Vilnius, 20110413.

${ }^{26}$ Ten pat.

${ }^{27}$ LR specialiojoje misijoje dalyvavęs civilis (1), ekspertinis interviu, Vilnius, 20110504.
} 
Eksperto teigimu, atsakymų i klausimus, kylančius dèl karių ir civilių bendradarbiavimo, dokumentuose ieškoma tik tada, kai susiduriama su tokiomis bendros veiklos koordinavimo problemomis, kurių jau nebeįmanoma išspręsti iprastu tarpasmeninès komunikacijos būdu.

Atsižvelgiant i ekspertų komentarus, galima reziumuoti: be to, kad Lietuvos PAG veikla yra organizuojama autonomiškai nuo kitų ISAF misijos kontekste veikiančiu PAG, ji kinta ir su kiekviena nauja Lietuvos karių rotacija ir civilių pamaina, atvykstančia į Gorą. Sąlygas ịsitvirtinusiam ad hoc veiklos organizavimo būdui per tarpasmeninius karių ir civilių ryšius sudaro minimalus PAG procedūrinių reguliavimų kiekis. Tinklaveikos visuomenès teorijos terminais kalbant, tokia situacijų kaitai jautri efemeriškumo kultūra yra būtina, kai yra veikiama susipynusių saugumo, ekonominių, politinių ir socialinių problemų aplinkoje. Kituose poskyriuose analizuojama, kaip karių ir civilių bendradarbiavimo efemeriškumas yra suderinamas su siekiu vykdyti koordinuotą veiklą - pristatomi vidinis ir išorinis PAG bendradarbiavimo tinklai, per kuriuos atsiskleidžia tinklaveikos visuomenès teorijoje aprašyta nesustabarejusių ekspertinių komandų kūrimo idejja. Taip pat pateikiamas PAG egzistuojančios horizontaliosios informacijos infrastruktūros, teoriškai turinčios panaikinti didžiausią tinklo organizacinès formos trūkumą - koordinacijos stoką - vertinimas.

\subsection{PAG vidinis ir išorinis bendradarbiavimo tinklas}

I vidinį PAG bendradarbiavimo tinklą sudarančius komponentus yra nurodoma Tvarkos apraše, teigiant, kad PAG yra „bendra karinè ir civilinè misija, kurioje dalyvauja Karinis vienetas ir Civilinis elementas“. Šis teiginys parodo, kad nors PAG instrumentu siekiama sujungti karių ir civilių patirtis, nèra stengiamasi sukurti visapusiškai vienalytę karių ir civilių komandą. Tikslas yra išlaikyti vidinės organizacijos prasme autonomiškus karinị vienetą ir civilinį elementą ir tuo pačiu metu užtikrinti jų bendradarbiavimą ir veiklos koordinavimą, siekiant bendrų misijos tikslų: „abu elementai atskirai reguliuoja savo vidinę veiklą, glaudžiai konsultuodamiesi“ ${ }^{\text {“28 }}$ . Pasak kalbinto eksperto, „[t]ai yra du atskiri vienetai, atskiri planavimai, atskiros procedūros, atskiri raportavimo šaltiniai. [...] Netgi kultūrine prasme, tai yra du skirtingi vienetai. Jų misijos yra skirtingos, tikslai skirtingi, veikimo principai skirtingi. ${ }^{\text {"29 }}$ Šis aspektas atspindi tinklaveikos fenomeno specifiką: siekiant užtikrinti struktūros

\footnotetext{
${ }^{28}$ Buvęs LR specialiosios misijos Afganistane vadovas (1).

${ }^{29}$ Buvęs LR specialiosios misijos Afganistane vadovas (2), ekspertinis interviu, Vilnius, 20110419.
} 
lankstumą, bendradarbiavimo tinklo dalyviai nèra integruojami ị vieną procedūrinị darini - jie išlaiko vidinę jurisdikciją, tačiau tarpusavio bendradarbiavimo lygmenyje yra jungiami bendrų veiklos tikslų.

Nepaisant išlaikomos vidinès karinio vieneto ir civilinio elemento autonomijos, tokia PAG komanda vis vien yra vieninga: „PAG galima būtų pavadinti „subalansuota "komanda, kuriojeyralabai skirtingųir skirtingas užduotis vykdančių, skirtingai atrodančių „žaidëjų “. Homogeniška komanda PAG pavadinti neišeitų dèl principinių skirtumų tarp ją sudarančių organizacijų - karinių ir civilinių institucijų, savo veikloje besivadovaujančių konkrečiomis procedūromis (ypač karinis PAG elementas). “30 Šiame karių ir civilių bendradarbiavimo lygmenyje svarbus aspektas yra ne tik tai, kad egzistuoja du, vidinès organizacijos prasme, vienas nuo kito nepriklausomi PAG komponentai, bet ir tai, kad jiems atitinkamai vadovauja du atskiri vadovai: PAG karinis vadas ir PAG civilinis vadovas. Pagal visaapimančio požiūrio koncepciją ir platesniame lygmenyje - pagal tinklaveikos visuomenės teoriją, sujungiant skirtingų profilių veikèjus bendram tikslui, turètų būti vengiama vieno elemento dominavimo kito atžvilgiu. Formaliai, remiantis Tvarkos aprašu, karinis vadas ir civilinis vadovas yra lygiaverčiai ir tarp jų neegzistuoja jokie tiesioginio ar netiesioginio pavaldumo ryšiai. Vis delto, buvusio LR specialiosios misijos vadovo teigimu, de facto jie yra nelygiaverčiai dèl to, kad civilių yra mažiau ir dèl to, kad jie yra visiškai priklausomi nuo kariuomenès saugumo, transportavimo ir dienotvarkès organizavimo klausimais. ${ }^{31}$ Taigi karinio vieneto funkcinè atsakomybè už civilių saugumo užtikrinimą yra bent jau teorinis svertas civilių veiklai apriboti.

Nors ị PAG veiklą ịtraukiant tiek karius, tiek civilius yra siekiama kiek imanoma išplèsti ekspertinių žinių, kuriomis disponuoja vidinio bendradarbiavimo tinklo dalyviai, mastą, Lietuvos vadovaujamo PAG atveju, lieka nemažai specifinių, Goro provincijos kontekste svarbių sričių, nesulaukiančių pakankamo specialistų dèmesio: 2009 m. Dalyvavimo Afganistane strategijoje yra aiškiai ịtvirtintas siekis ị PAG veiklą ịtraukti kuo daugiau ịvairių sričių specialistų - žemès ùkio, inžinierių ir t. t., tačiau realiai tokių itin reikalingų žmonių Lietuva nesiunčia ${ }^{32}$.

Šią spragą stengiamasi užpildyti vidinị PAG bendradarbiavimo tinklą papildant išorinių veikejų ekspertine patirtimi. 2-ajame paveiksle pavaizduota PAG vidinio ir išorinio bendradarbiavimo tinklo specifika.

\footnotetext{
${ }^{30}$ Karinèje misijoje dalyvavęs karininkas (2), ekspertinis interviu, Vilnius, 20110411.

${ }^{31}$ Buvęs LR specialiosios misijos Afganistane vadovas (1).

${ }^{32}$ Karinejje misijoje dalyvavęs karininkas (3), ekspertinis interviu, Vilnius, 20110419.
} 


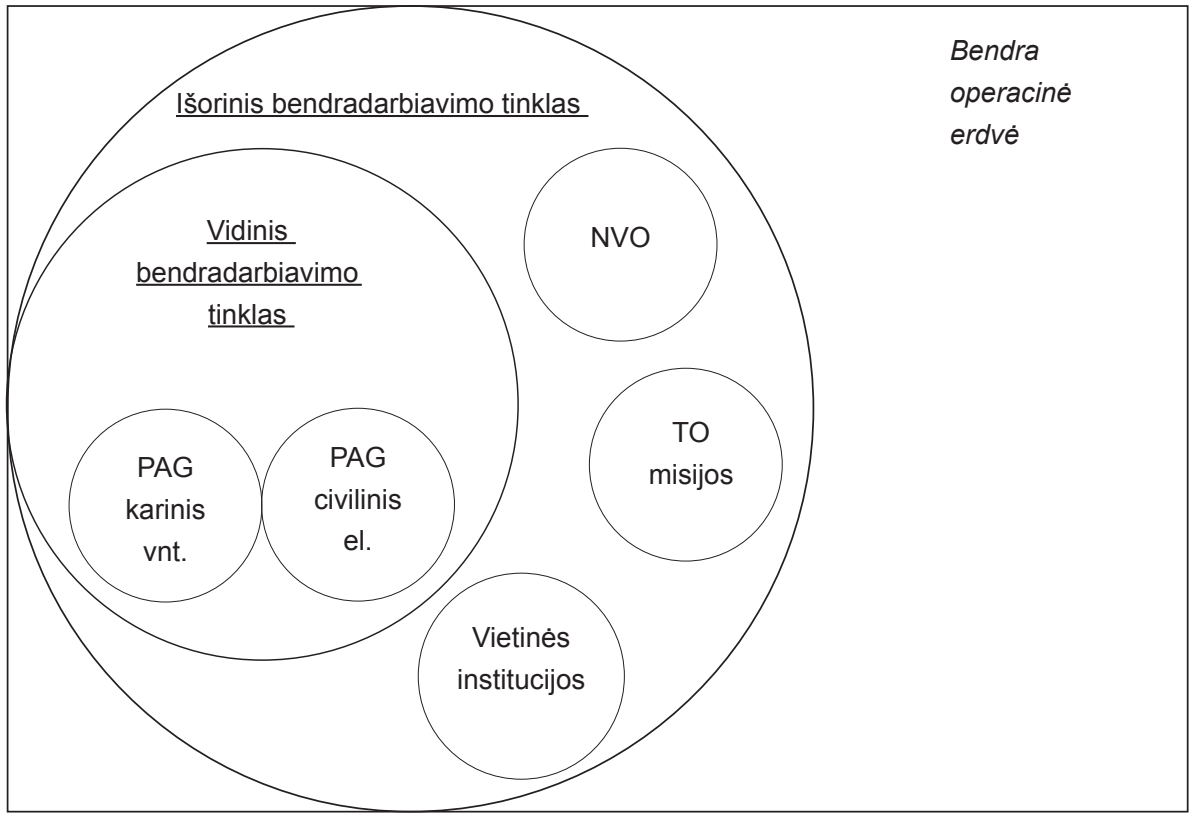

2 pav. PAG vidinis ir išorinis bendradarbiavimo tinklas

Išorinį bendradarbiavimo tinklą sudaro vietinès institucijos, tarptautinès organizacijos, tarptautinès ir vietinès NVO, kurios yra glaudžiai susijusios su PAG karių ir civilių vykdoma veikla ir ją tam tikra prasme pratęsia. Šių trijų profilių - karinio, civilinio-politinio ir civilinio-nevyriausybinio - veikejjų itaka provincijos atkūrimui gali būti analizuojama laiko atžvilgiu: „NVO sukuria ilgalaikį efektą, kitaip negu mūsiškiai $P A G$ 'e ir visas civilinis elementas. Civilinis elementas turi vis kiek trumpalaikiškesnį efektą, o mums reikia tokio efekto, kad mus toleruotų. [...] Yra tas pats veikimas toje erdveje, tik interesas laiko atžvilgiu skiriasi““. ${ }^{33}$

Apibendrinant, PAG ir NVO bendradarbiavimas bent jau teoriškai turètų būti svarbus abiems pusėms: NVO veiklos vykdymui reikalinga saugi aplinka, kurios kūrimas yra PAG karinio vieneto užduotis, o PAG dirbantiems kariams ir civiliams būtina žinoti apie visuomenèje vyraujančias nuotaikas - tai informacija, kurią gali suteikti NVO. Dẻl sukurtų tvirčiausių ryšių su vietiniais gyventojais ir geriausio jų poreikių išmanymo, „nevyriausybininkai iš esmès yra viso vystomojo bendradarbiavimo pagrindas. " ${ }^{\text {"34 }}$ Turint omenyje šị PAG ir išorinio bendradarbiavimo tinklo dalyvių veiklas jungiantị aspektą, nesunkiai įžvelgiamas

\footnotetext{
${ }^{33}$ Buvęs PAG vadas (1).

${ }^{34}$ Buvęs LR specialiosios misijos Afganistane vadovas (1).
} 
jau aptartas tinklo organizacinès struktūros ypatumas - vieni tinklo dalyviai yra priklausomi nuo kitų kontroliuojamų resursų.

Nors, visų ekspertų nuomone, PAG karių ir civilių bendradarbiavimas su Gore veikiančiomis NVO, išskyrus kelis nežymius atvejus, yra geras, remiantis britų NVO Global Partners atstovo patirtimi, ryšiai su lietuvių PAG dirbančiais civiliais ir jo vadovaujama NVO buvo pavieniai ir gana paviršutiniški, o lietuvių karinis vienetas apskritai nerodè didesnio susidomėjimo bendradarbiavimu. Kita vertus, ekspertas išreiške ir savo paties neigiamą požiūrị i veiklą, kurią Goro provincijoje ir, apskritai, Afganistane vykdo PAG. Jo teigi$\mathrm{mu}, \mathrm{PAG}$ buvimas ne tik nepagerina saugumo situacijos provincijoje, bet dèl vietinių pasipiktinimą keliančio fakto, kad jų šalyje yra dislokuotos tarptautinès karinès pajègos, išprovokuoja papildomas saugumo problemas, trukdančias NVO veiklos vykdymui. ${ }^{35}$

Greta Goro provincijoje veikiančių NVO, provincijoje taip pat dirba tarptautinių organizacijų atstovai. Viena iš jų - JT pagalbos misija Afganistane (angl. santrumpa - UNAMA), kurios pagrindiniai siekiai yra taikos proceso politinių ir strateginių konsultacijų teikimas, parama Afganistano vyriausybei, žmogaus teisių rẻmimas, techninès paramos teikimas, JT humanitarinès pagalbos, atkūrimo, atstatymo ir plètros veiklų valdymas ir koordinacija su šalies vyriausybe. ${ }^{36} \mathrm{Be}$ JT misijos taip pat veikia ES EUPOL misija, skirta Afganistano nacionalinès policijos apmokymui ir plètros priežiūrai. ${ }^{37}$ Kalbant apie vietinius veikejus, su kuriais ryšius palaiko PAG atstovai, buvo išskirti Goro provincijos gubernatorius, Afganistano nacionalinès policijos viršininkas ir saugumo tarnybos viršininkas. ${ }^{38}$

Iš atliktų interviu paaiškejjo, kad operaciniame lygmenyje bendradarbiavimas su UNAMA yra gana ribotas: „, [s]u UNAMA palaikydavom radijo ryšt iš principo... Vieną kartą per parą pasitikrindavome radijo ryšius. ${ }^{\text {"39 }}$ Tas pats pasakytina ir apie veiklos koordinavimą su EUPOL: „[p]agrinde bendradrabiavimas su EUPOL 'u vyksta strateginiame lygmenyje. Su jais yra sudaryta bendradarbiavimo sutartis. Bet šiaip, jie yra visai atskira organizacija ir jeigu jie nori, jie su mumis gali absoliučiai nieko nesiderinti. ${ }^{\text {“40 }}$ Nors tiek UNAMA, tiek EUPOL misija, tiek vietinès institucijos, būdamos atskiri autonomiški organizaciniai dariniai ir ben-

\footnotetext{
${ }^{35}$ NVO atstovas, ekspertinis interviu, 20110423.

${ }^{36}$ Lietuvos Kariuomenè, ,UNAMA“, $<$ http://kariuomene.kam.lt/lt/tarptautines_operacijos_786/afganistanas_2730/unama.html> [žiūrèta 201105 10].

${ }^{37}$ Lietuvos Kariuomenè, ,EUPOL Afghanistan“, <http://kariuomene.kam.lt/lt/tarptautines_operacijos_786/afganistanas_2730/eupol_afganistan.html> [žiūrèta 201105 10].

${ }^{38}$ Buvęs PAG vadas (2), ekspertinis interviu, Vilnius, 20110415.

${ }^{39}$ Karineje misijoje dalyvavęs karininkas (4), ekspertinis interviu, Vilnius, 20110418.

${ }^{40}$ LR specialiojoje misijoje dalyvavęs civilis (1).
} 
dradarbiaudami su PAG bendrų - provincijos atkūrimo ir vystymo - tikslų labui formaliai atitinka tinklo organizacinès struktūros tipą, realiai, kontroliuojamų ekspertinių resursų atžvilgiu, jos yra vienos nuo kitų pernelyg nepriklausomos ir dèl to nesuinteresuotos plètoti glaudesnio bendradarbiavimo. Kas kita pasakytina apie PAG ir NVO ryšius. Kadangi PAG buvimas provincijoje nevyriausybininkams garantuoja prieglobstị krizinės saugumo situacijos atveju, o NVO disponuoja PAG veikloms vykdyti reikalinga informacija apie socialinę padèti provincijoje, šie dviejų tipų veikejai - nors formaliai veikiantys itin skirtingais metodais - yra priversti palaikyti nuolatinius bendradarbiavimo ryšius. Dèl šios priežasties galima apibendrintai teigti, kad PAG vidinị bendradarbiavimo tinklą kokybiškai ir svariai papildo šiaip jau silpnai veikiančio išorinio bendradarbiavimo tinklo veikẻjai - NVO.

\subsection{Horizontalioji informacijos infrastruktūra}

Vienas iš esminių aspektų, siekiant palaikyti efektyvaus bendradarbiavimo tinklą tarp ịvairių profilių veikejų, yra horizontaliosios informacijos infrastruktūros sukūrimas. Tokio tipo infrastruktūroje informacija aktualiais klausimais yra dalijamasi tarp visų tinklui priklausančių elementų tam, kad būtų užtikrintas visapusiškas operacinès erdvès, kurioje yra vykdoma veikla, specifikos suvokimas. Kalbant apie horizontalujj pasikeitimą informacija vidiniame bendradarbiavimo tinkle - tarp PAG karinio vieneto ir PAG civilinio elemento, svarbiausias instrumentas yra susitikimų formatas: organizuojami kasrytiniai, savaitiniai susitikimai, kurių metu visi PAG priklausantys asmenys aptaria einamuosius klausimus, pateikia raportą apie atliktą veiklą, derina pozicijas, kaip turètų būti igyvendinama ISAF vado priskirta konkreti užduotis. ${ }^{41}$ Be šio pagrindinio horizontaliosios informacijos sklaidos instrumento, paminètina ir interaktyvioji duomenų bazé, kurioje yra sisteminama informacija apie gyventojus, jų poreikius, išvykimus iš PAG stovyklos. ${ }^{42}$ Susitikimų formato ir duomenų bazès, kaip priemonių efektyviai informacijos sklaidai užtikrinti, sujungimas yra svarbus, nes leidžia informaciją perduoti tiek einamuoju laikotarpiu, tiek ir susisteminti ir platinti konkrečias „išmoktas pamokas“.

Be realiai egzistuojančių instrumentų informacijai perduoti, kertinis horizontaliosios informacijos infrastruktūros ịtvirtinimo aspektas yra informacijos filtravimo apribojimas - tinklo dalyviai privalo disponuoti išsamiomis žiniomis apie vieni kitų veiklas tam, kad būtų užtikrintas pakankamas autonomiškų vei-

\footnotetext{
${ }^{41}$ Buvęs LR specialiosios misijos Afganistane vadovas (1).

${ }^{42}$ Karinèje misijoje dalyvavęs karininkas (5), ekspertinis interviu, Vilnius, 20110415.
} 
kèjų tarpusavio koordinacijos lygis. Dèl jau minèto ị PAG veiklą jeinančios saugumo srities specifiškumo ir iš to išplaukiančių galimybių kariniam vienetui subordinuoti civilius, esminis klausimas yra, ar kariai dalijasi išsamia informacija su civiliais. Pasak buvusio LR specialiosios misijos vadovo, „[k]itaip absoliučiai būtų neįmanoma, jeigu nebūtų informacija dalijamasi kompetencijos ribose. ${ }^{\text {"43 }}$ Eksperto teigimu, yra sričių, kuriose karinis vienetas neturi dalintis informacija su civiliais arba turi tai daryti selektyviai, tačiau tas pats galioja ir civiliams: yra informacija, kuri kariams būtų perteklinè ir nereikalinga. ${ }^{44}$

Silpniau veikiančio išorinio bendradarbiavimo tinklo ribose taip pat yra palaikomi nuolatiniai kontaktai. Kalbant apie ryšius su vietos valdžia, „būdavo ir planiniai susitikimai, važiuodavom pas vietinę valdžią, nes porą kartų per savaitę būdavo vadinamosios šūros. ${ }^{\text {"45 }}$ Remiantis ekspertais, visada kreipiamas dèmesys $\mathfrak{i}$ tai, kad tokiuose susitikimuose dalyvautų tiek karinio, tiek civilinio komponentų atstovai, kurie turi didžiausią ekspertinių žinių bagažą konkrečiais, susitikimams numatytais klausimais. ${ }^{46}$ Šiuo aspektu vèlgi pabrèžiamas PAG veikimas ad hoc ekspertinių komandų būdu - kadangi informaciją rūpimais klausimais geriausiai surinkti gali konkečioje srityje didžiausią ekspertinę patirtị turintys asmenys, su išoriniais veikejjais bendradarbiauja abiejų komponentų atstovai neatsižvelgiant $\mathfrak{i}$ karių ir civilių skirtị.

Kaip jau minèta, PAG veiklos vykdymui itin svarbios Goro provincijoje veikiančios NVO. Poreikis keistis informacija su jomis itin ryškus ne tik civilinio elemento, bet ir karinio vieneto atveju. Pasak kalbinto eksperto, NVO turima informacija yra itin svarbi Afganistano „humanitarinio paveikslo" rengimui: informacijos apie žmones kamuojančias problemas, mirtingumą, ligų paplitimą ir nusikalstamumo lygị rinkimas. Eksperto teigimu, niekas, ǐsskyrus NVO, negali surinkti tokios detalios informacijos. Be to, kad PAG veiklai būtina NVO teikiama informacija, pačios NVO yra taip pat suinteresuotos informacijos pasikeitimu - jas labiausiai domina informacija apie saugumą, kurią gali suteikti PAG karinio vieneto atstovai, kadangi jie turi tiksliausius žemèlapius, geriausią informavimo sistemą ${ }^{47}$

Vis dèlto, NVO eksperto teigimu, jo atstovaujama organizacija gaudavo itin mažai informacijos iš lietuvių PAG, nors reikalavimų informuoti apie jų organizacijos vykdomą veiklą patys „nevyriausybininkai“ iš PAG sulaukdavo nuolat. ${ }^{48}$ Tokios situacijos susidarymą kitas kalbintas ekspertas aiškino teigda-

\footnotetext{
${ }^{43}$ Buvęs LR specialiosios misijos Afganistane vadovas (1).

${ }^{44}$ Buvęs PAG vadas (1).

${ }^{45}$ Buvęs PAG vadas (2).

${ }^{46}$ Buvęs PAG vadas (3), ekspertinis interviu, Vilnius, 20110429.

${ }^{47}$ Karinèje misijoje dalyvavęs karininkas (5).

${ }^{48} \mathrm{NVO}$ atstovas.
} 
mas, kad NVO lengviau gali suteikti informacijos negu ISAF apribojimų paisyti turinčios PAG. ${ }^{49}$ Šiuo atveju galima kalbeti apie informacijos asimetrijos problemos formavimąsi: dèl to, kad didelè dalis ISAF informacijos yra skirta tik vidiniam PAG naudojimui, jame dirbantys kariai ir civiliai negali vykdyti kokybiškų informacijos mainų su NVO sektoriumi - iš esmès šios situacijos pralaimètojos yra abi pusès, negalinčios disponuoti visa informacija.

Apibendrinant tiek, konkrečiai, išsamaus dalijimosi informacija tarp skirtingų profilių veikejų, ịtrauktų ị Goro provincijos atkūrimo veiklą, lygị, tiek, apskritai, veiklos tarp šių veikejų reglamentavimo lygị ir koordinaciją, galima teigti, kad PAG sąlygos lankstumui ir horizontaliajai sąveikai yra sudarytos. Goro provincijoje dirbantys veikejai gali koordinuoti tarpusavio veiklą, netrukdomi perteklinio formaliụjų reguliavimų ir procedūrinių reikalavimų kiekio, ir tokiu būdu disponuoti plačiu išsamios informacijos nuo realios saugumo situacijos iki provincijoje gyvenančių žmonių poreikių diapazonu. Didžiausias kliūtis visapusiškam bendradarbiavimui ir pasikeitimui informacija sukuria veikimas su saugumo klausimais susijusioje srityje - tai yra neišvengiamas veiksnys, sukuriantis ribas tinklaveikos principu igyvendinimui PAG kontekste.

\subsection{Kariụ ir civiliụ organizacinių kultūrų susidūrimas}

Kita galima kliūtis tinklaveikos fenomeno įsigalèjimui karinèje sferoje susidaro kultūriniame lygmenyje. Neišvengiamai kyla klausimas, ar gali būti palaikomas efektyvus bendradarbiavimas tarp griežta disciplina, aiškiais pavaldumo ryšiais ịpratusių vadovautis karių ir kur kas lanksčiau savo veiklą organizuojančiu civilių, taip pat tarp karių, kurie yra valstybinio prievartos aparato atstovai, ir NVO aktyvistų, besilaikančių neutralumo, humaniškumo ir bešališkumo principų ${ }^{50}$.

Pirmaisiais PAG egzistavimo metais, pasak LR specialiosios misijos vadovo, civilinio komponento atstovams teko tam tikras "posūnio, podukros" vaidmuo. Tai, visų pirma, lèmé faktas, kad Lietuvos karinè misija Gore èmé veikti kiek anksčiau nei LR specialioji misija: „,[k]ai buvo deleguotas pirmasis diplomatas, kuris buvo visų galų specialistas viename asmenyje, tai jis iš tiesų turejjo labai iškovoti vietą po saule, nes kariai nematė poreikio jame. ${ }^{\text {" } 51}$ Eksperto teigimu, reikejjo laiko ir pastangų, kad būtų ịtvirtinta idejja, jog Gore veikia

\footnotetext{
${ }^{49}$ LR specialiojoje misijoje dalyvavęs civilis (1).

${ }^{50}$ Laure Borgomano-Loup, ,Improving NATO-NGO Relations in Crisis Response Operations“, NATO

Defense College "Forum Papers Series", Rome, 2007, 33.

${ }^{51}$ Buvęs LR specialiosios misijos Afganistane vadovas (1).
} 
mišri, o ne išskirtinai karinè misija. Turèjo būti pripažintas ne tik dvigubas karinis-civilinis misijos pobūdis, bet ir to pasekmès - lankstesnio požiūrio ị misijos tikslu ịgyvendinimą būtinybè.

Nors formaliai Tvarkos apraše karinès ir specialiosios misijų lygiavertiškumas atsiskleidžia per nesubordinuotus karinio vado ir civilinio vadovo ryšius, realiai „civilių subordinacija jaučiama $<\ldots>$ Misijoje negali būti dviejų vadų. ${ }^{\text {"52 }}$ Tai, kad neretai dèl saugumo srities specifikos kariškiai suabsoliutina karinio vieneto svarbą ir apie ji kalba taip, lyg PAG karinio vieneto egzistavimas savaime reikštų karių vykdomos veiklos viršenybę civilinės veiklos atžvilgiu, patvirtina kariškiams tradiciškai itin svarbus veiksmų planavimo aspektas: „[m]es gerai sutarem, gal tik pradžioj civiliams buvo sunku įsivažiuoti - jie nesuprasdavo, kad reikia planuoti. [...] Po to mes jau juos išmuštravom. " ${ }^{53}$

Didžioji dalis kalbintų ekspertų neigè civiliams primetamų kariškų darbo metodų egzistavimą ir pabrežè, kad kiekviena situacija gali būti sprendžiama vis kitu būdu, priklausomai nuo konkrečių žmonių įsivaizdavimo, kaip tai turètų vykti: „[k]artais civilinèse organizacijoje egzistuoja griežtesnè tvarka nei kariuomenejje ir, atvirkščiai, gali būti kariuomenëje tokie vienetai, kur ta tvarka griežtumo atžvilgiu yra mažesnè nei civiliniame gyvenime. [...] Viskas priklauso nuo žmogaus savybių. ${ }^{\text {"54 }}$ Asmenybių aspektą minèjo kone visi ekspertai, teigdami, kad sèkmingam bendradarbiavimui PAG didžiausią įtaką turi žmogaus pasiryžimas siekti kompromiso, o ne tai, ar jis yra kariškis ar civilis.

Nepaisant asmeninių savybių svarbos, karių, kaip specifinès grupès, identifikacijos aspektas yra ryškus. Kaip teigè buvęs PAG vadas, „jeigu mūsų kas paklaus, ar mes galim be civilių, tai, aišku, sakysim - mes galim. Mes viską galim. Mes tam ir esam, kad viską galètume, čia tokia organizacinè kultūra. " ${ }^{\text {"55 }}$ Tokie komentarai demonstruoja bendrą tendenciją, kad, kaip teigè kalbintas LR specialiosios misijos dalyvis, pastaruoju metu kariai išeidami už savo komunos tipo bendruomenès ribų ir igydami vis daugiau visuomeninių žinių ir patirties, kuriomis anksčiau disponavo vien tik civiliai, jaučiasi galintys ịvykdyti vis didesnị spektrą užduočių - civiliai laikomi tik pagalbine jèga. ${ }^{56} \mathrm{Be}$ to, kad vis didesnis kiekis žinių, kurias pastaruoju metu igyja kariai, lemia didejjančią konkurenciją su civiliais, taip pat tam tikros sąmoningos ar nesąmoningos nuoskaudos bendradarbiavimo nepalengvina: „[k] adangi visose NATO šalyse yra pripažįstama, kad virš kariuomenès yra civilinis vadovavimas strateginiu lygmeniu, kariai - man iš patirties atrodo, kad jie traumą

\footnotetext{
${ }^{52}$ Buvęs LR specialiosios misijos Afganistane vadovas (2).

${ }^{53}$ Karinèje misijoje dalyvavęs karininkas (5).

${ }^{54}$ Buvęs PAG vadas (3).

${ }_{55}^{55}$ Buvęs PAG vadas (1).

${ }^{56}$ LR specialiojoje misijoje dalyvavęs civilis (1).
} 
turi: generolai juk ne kvailesni už civilius, todèl jie mano, kad gali viską padaryti taip pat gerai kaip ir civiliai. Todel jų čia iš vis nereikia. ${ }^{\text {"57 }}$

Karių ir civilių bendradarbiavimą vertinant kultūriniu požiūriu, dar didesni prieštaravimai kyla tarp PAG, kaip karinio ir civilinio instrumento, ir NVO veiklos koordinavimo. Kaip jau minèta šiame straipsnyje, NVO veiklos kodekse yra ịtvirtinti neutralumo, bešališkumo, humaniškumo principai, kurie akivaizdžiai kertasi su karių, kaip valstybinès prievartos igyvendintojų, veikimo būdais. Šị aspektą aiškiai ịvardijo kalbintas NVO atstovas, paklaustas, kokią ittaką NVO veiklai daro toje pačioje funkcineje erdvëje veikiantys kariai: „[n]ors karių buvimas suteikia bendrą saugumo jausmą ir, iškilus saugumo krizei, užsienio aktyvistams garantuoja prieglobsti, egzistuoja ir tam tikra ju buvimo sukeliama žala. Didelis karių, svetimų vèliavų ir karinių transporto priemonių matomumas traukia dèmesí, todèl NVO darbuotojai turi vengti būti šalia tokių akivaizdžių taikinių. Bendrai kalbant, manau, kad NVO geriausia vengti būti asocijuojamoms su karinèmis pajègomis" ${ }^{\text {“ }}{ }^{8}$

Vis dèlto, remiantis kitų ekspertų nuomone, NVO veiklos kodeksu ne visada yra visiškai vadovaujamasi veikiant realiose situacijose. Lietuvos PAG egzistavimo laikotarpiu ivyko ne vienas vadinamasis „saugumo susitikimas“, skirtas pasikeitimui aktualia informacija su Goro provincijoje veikiančiomis NVO. ${ }^{59} \mathrm{Be}$ to, svarbu, kad kiekviena NVO nare savo veiklą organizuoja labai individualiai: „[y]ra tokių, kurios persmelktos kraštutinio pacifizmo, bet jų nèra daug, o visos kitos bendradarbiauja labai puikiai tiek formaliam, tiek neformaliam lygmenyje. " ${ }^{60}$ Pabrèždamas kiekvienos NVO narès, o taip pat ir kitų Afganistane veikiančių organizacijų, veiklos specifiškumą, atsižvelgiant ị provincijos, kurioje veikiama, socialines sąlygas ir talibano paplitimo lygị, buvęs LR specialiosios misijos vadovas pastebëjo, kad egzistuoja natūralus, saugumo situacijos kaitą atitinkantis dėsnis kuo toliau i pietus, tuo mažesnis NVO noras bendradarbiauti su PAG. ${ }^{61}$

Visi šiame poskyryje minèti karių ir civilių organizacinių kultūrų susidūrimo aspektai gali būti apibendrinti išvada, kad veikiant tokioje kompleksiškoje aplinkoje, kaip šiandieninis Afganistanas, jokie apibendrinimai negalioja. Nors galima ižzvelgti tiek karių, kaip uždaros izoliuotos grupès, tiek civilių, kaip patariamojo balso, tiek NVO kaip vengiančių identifikavimo su karinèmis organizacijomis tendencijas, tačiau realios šių tendencijų apraiškos yra veikiau konkrečių asmenybių ir tam tikrų situacijų, o ne nusistovejjusių praktikų klausimas.

\footnotetext{
${ }^{57}$ Ten pat.

${ }^{58} \mathrm{NVO}$ atstovas.

${ }^{59}$ Karinèje misijoje dalyvavęs karininkas (5).

${ }^{60}$ Karinèje misijoje dalyvavęs karininkas (4).

${ }^{61}$ Buvęs LR specialiosios misijos Afganistane vadovas (2).
} 


\section{Išvados}

Pastaruoju metu kone visose žmogaus veiklos srityse aiškiai reglamentuota, struktūruota ir vienadimensiška veikla užleidžia vietą dinamiškam, kompleksiškam ir ịvairias patirtis jungiančiam veikimo būdui. Tai lemia tiek sparčiai besivystančios technologijos, kurios išplečia galimybes plètoti inovatyvią veiklą, tiek ir atitinkamai didejantis poreikis spręsti „inovatyvias“, daugiadimensines problemas. Šių pokyčių rezultatas yra ịsivyraujanti tendencija, kuri pasireiškia kaip visose žmogaus veiklos sferose egzistuojančių organizacijų veiklos logikos ir darbo strategijos kaita: tradiciškai nusistovejusios hierarchinès struktūros yra keičiamos mažiau strukūruotais, lanksčiau veikiančiais ir ne ì procedūras, bet ị tikslą orientuotais organizaciniais dariniais - tinklais.

Atsižvelgiant $\mathfrak{i}$ šias bendras tendencijas ir įvertinus funkcijas, kurias pastaruoju metu vis dažniau vykdo karinės organizacijos (krizių valdymas, pokonfliktinis atkūrimas), straipsnyje buvo remtasi prielaida, kad tinklaveikos fenomenas ịsigali ne tik ekonominèje, politinèje, socialinėje, bet ir tradiciškai hierarchinèje karinejje srityje. Šiai prielaidai patikrinti straipsnyje buvo sugretinti tinklaveikos ir NATO visaapimančio požiūrio principai, o gautų paralelių pagrịstumas buvo tikrinamas, atliekant kokybinį visaapimančio požiūrio îgyvendinimo Lietuvos vadaujamoje PAG Afganistano Goro provincijoje tyrimą. Tyrimo rezultatai atskleide tinklaveikos fenomeno plitimo karinèje srityje galimybes ir ribas (žr. 3 lentelè).

3 lentelè. Tinklaveikos fenomeno plitimo karinèje srityje galimybẻs ir ribos

\begin{tabular}{|c|c|}
\hline Tinklaveikos logika PAG & Veiksniai, ribojantys tinklaveiką PAG \\
\hline $\begin{array}{ll}\text { 1. } & \text { nestandartizuoti dariniai ISAF misijos } \\
\text { 2. rèmuose } \\
\text { 3. minimalus pagrindu kintanti konfigūracija } \\
\text { 4. autonomiški karinis ir civilinis komponentai } \\
\text { 5. ekspertinių patirčių sujungimas } \\
\text { 6. horizontalioji infrastruktūra }\end{array}$ & $\begin{array}{l}\text { 1. saugumo srities specifiškumas } \\
\text { 2. išlaikoma hierarchiška karinio vieneto vidinè } \\
\text { vadovavimo ir kontrolès struktūra } \\
\text { 3. karių kaip atskiros visuomenès grupès } \\
\text { tapatybè } \\
\text { 4. augantis karių tarpdisciplininių žinių bagažas }\end{array}$ \\
\hline
\end{tabular}

PAG organizacinèje logikoje galima atpažinti tinklaveikos principus. Šie dariniai yra mažai reglamentuotos struktūros, kurių konfigūracija kinta, atsižvelgiant ị konkrečios rotacijos tikslą, saugumo situaciją, provincijoje aktualias problemas. Ribotas formalių procedūrų ir reguliavimų kiekis atitinka tinklaveikos visuomenès teorijoje akcentuojamą būtinybę veikti lanksčiai, atsižvelgiant i konkrečioje situacijoje esančias sąlygas. Be to, PAG sudarančius karinị vienetą ir civilinį elementą jungia ne bendra organizacinė struktūra, bet bendras tiks- 
las. Karių ir civilių veiklai koordinuoti yra užtikrinama horizontali informacijos sklaida. Išimtis galima siekiant prieiti prie įslaptintos informacijos. Galiausiai, PAG yra siekiama sujungti platų ekspertinès patirties spektrą: PAG priklausantys kariai ir civiliai bendradarbiauja su NVO, tarptautinemis organizacijomis, vietinėmis institucijomis. Iš šių išorinių veikèjų PAG karių ir civilių veikla aktyviausiai derinama su NVO, kadangi jos yra ịrankis vystomojo bendradarbiavimo projektams, už kuriuos yra atsakingas PAG civilinis elementas, igyvendinimui. Kadangi PAG ir tarptautinių organizacijų ir vietinių institucijų veikla konkrečių sąlyčio taškų neturi, todèl su jais yra palaikomas veikiau formalus ryšys.

Nors tyrimas pademonstravo, kad bendrieji tinklaveikos fenomeno principai yra aiškiai atkartojami NATO visaapimančio požiūrio koncepcijoje ir dèl to yra igyvendinami Lietuvos PAG Afganistano Goro provincijoje, egzistuoja ir tam tikri tinklaveikos principų taikymą karineje srityje ribojantys veiksniai. Vienas iš jų yra neišvengiamas PAG funkcionavimas jautriame saugumo klausimų kontekste. Būdami atsakingi už PAG stovyklos saugumą, kariai igyja svertus kontroliuoti civilinį elementą ir apriboti jo autonomiją, tokiu būdu pablogindami civilių ekspertinès patirties sklaidą. Be to, karių disponavimas įslaptinta informacija daro neịmanomus lygiaverčius informacijos mainus su civiliais ir NVO atstovais - šis faktas pagilina asimetriją karių ir civilių bendradarbiavime.

Antra, koordinuojant karių ir civilių veiklą tiek PAG viduje tarp karinio vieneto ir civilinio elemento, tiek išoreje su NVO, kyla kultūrinio lygmens problemų. Nors interviu metu visi kalbinti buvę PAG karinio vieneto atstovai teigè, kad jų santykiai su civiliais buvo geri ir svarbiausias yra asmenybių veiksnys, pokalbio eigoje dažnai išryškẻdavo požiūris, kad Afganistane kariai be „civiliokų“ išsiverstų gana lengvai, kad bendradarbiavimo santykiai su civiliais normalizuojasi, kai šie išmoksta iš anksto planuoti ir t. t. Šie aspektai demonstruoja vis dar gyvuojantị karių kaip atskiros grupés tapatybės aspektą, kuris tiek PAG atveju, tiek veikiant kariams ir civiliams ateityje gali trukdyti plètoti pilnaverčius bendradarbiavimo ryšius.

Nepaisant minètų specifinių karinès srities bruožų, kiek apribojančių tinklaveikos fenomeno principų ísigalèjimą šioje srityje, galima teigti, kad Lietuvos PAG Goro provincijoje yra inovatyvi organizacija, veikianti pagal lankstumo, organiškumo, mobilumo principus ir atsisakanti didelès dalies procedūrinių praktikų, būdingų tradiciškai hierarchinèms karinėms struktūroms. Šis aspektas parodo, kad visos viešojo gyvenimo sferos - ekonominé, politiné, socialinè, karine - yra susijusios glaudžiais ryšiais ir funkcionuoja pagal tą pačią konkrečiu laikotarpiu efektyviausią veiklos organizavimo logiką. 